\title{
Drivers of Indigenous Ghanaian Firms' Degree of internationalization
}

\author{
Lydia Nyankom Takyi \\ Akenten Appiah-Menka University of Skills Training and Entrepreneurial Development, Kumasi, Ghana \\ Email address: lynyankom@aamusted.edu.gh
}

\begin{abstract}
The study aims to investigate home country institutional environment factors influencing indigenous firms' internationalization in Ghana. Precisely, the study examines the relationship between pull factors, push factors and internationalization. The paper leads to a comprehensive understanding of factors driving firms' internationalization, which could facilitate government support for such indigenous firms. The first research objective is to explore how favourable domestic factors pull/induce internationalization in line with the institutional-based view. The second proposed research objective aimed to examine the relationship between unfavourable factors and the internationalization of indigenous Ghanaian firms. The study is based on an institutional-based view and employed an online survey questionnaire to sample 109 key informants actively involved in the export and management of the export business. The data obtained were analyzed using multiple regression. The data were analyzed using STATA version 13 software. Also, Pearson correlation, linear regression and multiple regress were used to determine the association. The findings from the study indicate a negative relationship between pull factors and internationalization, with push factors recording no significant effect on the internationalization of firms.
\end{abstract}

Keywords: Favorable factors, Pull factors, Unfavourable factors, Push factors, Indigenous firm, Institutions, Internationalization

DOI: $10.7176 /$ EJBM/14-3-05

Publication date: February $28^{\text {th }} 2022$

\section{Introduction}

The country-level institutional factors are central elements in the internationalization of firms (Bowen, 2019; Marinova \& Marinov, 2017); therefore, researching the institutional context is vital for a comprehensive understanding of the drivers of foreign market operations. Literature shows firms' nascent internationalization (Boso, Adeleye, Ibeh, \& Chizema, 2019; Omokaro - Romanus, Anchor, \& Konara, 2018). Similarly, research on the internationalization of African firms (Boso, Adeleye, Ibeh, \& Chizema, 2019) and drivers of internationalization (Rialp, Rialp, \& Knight, 2005) also proliferate in the extant literature. To some extent, the firm internationalization phenomenon has heightened scholarly interest in international business to examine the institutional environment factors driving firms' international operations.

Businesses are primarily driven by institutional factors that directly or indirectly induce their internationalization decision (Igwe Paul \& Kanyembo, 2019; Marinova \& Marinov, 2017). "Institutions are the rules of the game in a society or, more formally, are the humanly devised constraints that shape human interaction. Consequently, they structure incentives in human exchange, whether political, social, or economic" (North, 1990:3). Furthermore, Omokaro - Romanus, Anchor, \& Konara, 2018) assert that home country institutional "factors enabled the firms to acquire and accumulate the resources and capabilities, financial resources, knowledge, and experience, all of which provided the motivation, drive, and strength to internationalize" (p.8). However, despite the significant role played by the institution in firm internationalization, studies on drivers of internationalization are non-existent in the literature (Boso, Adeleye, Ibeh, \& Chizema, 2019). Besides, most of the existing studies focus mainly on the developed and emerging economies with a narrow focus on the developing economy (Igwe Paul \& Kanyembo, 2019). Given the seminal role of country-level institutions' factors on firms' foreign market operations, this paper examines how favourable and unfavourable institutional factors, proxy as pull and push factors, induce indigenous exporters' internationalization and argue that empirical.

The study is a response to Boso, Adeleye, Ibeh, and Chizema, 2019 call for an empirical study on the environmental factors influencing the internationalization of African firms and Bowen (2019) call for an in-depth study on a specific context that can enable a complete understanding of the impact of environmental factors on internationalization. Accordingly, the study developed two overarching hypotheses and employed a survey method to sample 109 indigenous SMEs in Ghana's export activities. The export directory was taken from the Ghana Export Promotion Authority (GEPA). Quaye, Sekyere, and Acheampong (2017) used the same export directory to investigate the link between export promotion programs and SMEs export performance in Ghana. The first proposed research question is whether favourable domestic factors are more likely to pull/induce internationalization in line with the institutional-based view. The second proposed research question is whether 
unfavourable factors in the home country are more likely to push/induce international activities. The remaining sections of the paper are structured as follows; a review on institutional-based view and hypothesis development, methodology, findings, and discussions. The next section presents the study's implication (theoretical and managerial), limitation, recommendation, and conclusion.

\section{Literature}

\subsection{Hypothesis development}

Firms' activities and internationalization are driven mainly by institutional factors' home country (Igwe Paul \& Kanyembo, 2019). Existing literature defined institutions as "formal structures responsible for guiding or curtailing the choices of agents with regards to the promotion of their international insertion and these structures can act in a positive, negative or even different manner" (Monticelli, Calixto, Vasconcellos, \& Garrido, 2017:350). Kraus, Mitter, Eggers, and Stieg (2017) classified these institutional factors as pull and push and acknowledged that firms are driven to the international market because of a saturated and competitive market and excessive regulations in the home country. Kraus, Mitter, Eggers, \& Stieg (2017) findings stemmed from the argument that unfavourable institutional factors at the home nation create a hostile environment that de-motivate individual with a high entrepreneurial mindset: in such instances, the individual is forced to seek market opportunities outside their home boundaries and to satisfy their need for personal accomplishment (Muralidharan \& Pathak, 2017).

Precisely, negative external institutional factors push or drive individuals or firms with a high entrepreneurial goal to the foreign market (Omokaro - Romanus, Anchor, \& Konara, 2018; Segal, Borgia, \& Schoenfeld, 2005). However, just like the institutional challenges, favourable institutional factors such as government incentives, increase in foreign demands, low-interest rates, tax exemption, tax holidays, among others, stimulate internationalization (Bowen, 2019; Monticelli, Calixto, Vasconcellos, \& Garrido, 2017; Omokaro - Romanus, Anchor, \& Konara, 2018; Seglah \& Armah, 2016). Therefore, in a favourable external environment, individuals with a high entrepreneurial orientation are motivated to take advantage of the opportunities to expand to the foreign market (Takyi \& Naidoo, 2020). This suggests that both favourable and unfavourable institutional factors are seminal in export activities since they both induce internationalization (Bowen, 2019; Muralidharan \& Pathak, 2017).

The institutional-based view argues that institutional factors boost or limit international decisions and produce negative, positive, or indifferent results (Monticelli, Calixto, Vasconcellos, \& Garrido, 2017). The decision to internationalize significantly relies on the home country institutional conditions (Bowen, 2019). Accordingly, the institutional-based view maintains that favourable institutional conditions create an enabling and friendly entrepreneurial environment that the firm leverage to develop a competitive advantage and influence internationalization (Bowen, 2019; Monticelli, Calixto, Vasconcellos, \& Garrido, 2017). Alternatively, an unfavourable institutional context creates a hostile entrepreneurial environment and stifles growth, entrepreneurial intentions, and opportunities; in such instances, individuals (businesses) with entrepreneurial intentions continue operation through seeking opportunities outside their country territories (Muralidharan \& Pathak, 2017; Shane, 2004). Therefore, institutional involve facilitators or hampers, which can be classified as pull and push drivers (Kraus, Mitter, Eggers, \& Stieg, 2017; Seglah \& Armah, 2016). This explains why the paper adopts the institutional-based view as the overarching theory to investigate the relationship between country-level institutional factors and SMEs' internationalization.

Omokaro - Romanus, Anchor, and Konara (2018), defined favourable institutional environmental factors as positive conditions, including the large domestic market that help businesses acquire the needed resources, competency, and competitiveness at both the domestic and international market (Monticelli, Calixto, Vasconcellos, \& Garrido, 2017), which the firm leverage on as a means of "motivation, drive and strength to internationalize (p. 8)". Recently, other scholars observed that foreign market requests and business contacts, market competition and growth, tax benefits, low-interest rates, tax exemption, tax holidays and tax subsidies all together drive firms' internationalization decision (Bowen, 2019; Epifanova, Romanenko, Mosienko, Skvortsova, \& Kupchinskiy, 2015; Monticelli, Calixto, Vasconcellos, \& Garrido, 2017; Omokaro - Romanus, Anchor, \& Konara, 2018). Francioni, Pagano \& Castellani (2016) review on drivers of SMEs in export activities revealed that the external institutional factors like a government support system, owner/management team social networks and entrepreneurial relationships with customers and distributors induce internationalization. Most recently, Safari and Saleh Ali (2020) and Morais and Franco (2018) suggested that favourable factors such as increasing network relationships significantly influence SMEs internationalization through enhanced firms international experience and increase market share. Therefore, such favourable factors seem to pay on firm resource acquisition, accumulation, competitiveness, and internationalization. Precisely, a comparative study on the motives of firms' internationalization found that a favourable institutional environment positively influences internationalization (Bowen, 2019). Therefore, the study argues that a favourable country-level institutional environment is more likely to enhance firms access to resources, improve capabilities, develop competitive advantage and engender 
internationalization. On the other hand, an unfavourable institutional environment will restrain firms with entrepreneurial intention, and in such instances, firms rely on the opportunities beyond their country territories and entry into the foreign market (Muralidharan \& Pathak, 2017). Therefore, extant literature found that albeit weak and unfriendly institutional environment constrain international operations (Korsakien, Diskien, \& Smaliukien, 2015; Morais \& Ferreira, 2020), it, however, also induce internationalization (Korsakien, Diskien, \& Smaliukien, 2015).

In their seminal study entitled "inducing the internationalization of family manufacturing firms from a transition context" Marinova and Marinov (2017) observed that firms are driven to the international market mainly to explore other market opportunities because of the persistent changes in government policies and programs, lack of institutional support, bureaucratic procedure, and loss of trust in the state institutions. Moreover, (Kraus, Mitter, Eggers, \& Stieg, 2017) observed in their study on German managers that businesses are driven to the international market due to market saturation and dominance, increased competition, exhausted or unsuitable diversification possibilities. The general literature discourse proves that a firm early entry into the foreign market is not necessarily to increase sales or profit (Marinova \& Marinov, 2017): but to take advantage of the foreign market opportunities; to overcome the home country environmental challenges such as market saturation, small domestic market size (Marinova \& Marinov, 2017; Morais \& Franco, 2018), high competitive market (Amungo, 2016), and unfavourable socio-cultural factors (Muralidharan \& Pathak, 2017). Morais and Ferreira (2020) found that lack of government support which is the major unfavourable institutional factor positively impacts internationalization (Monticelli, Calixto, Vasconcellos, \& Garrido, 2017; Morais \& Ferreira, 2020). Furthermore, Marinova \& Marinov (2017) study on factors driving international operation among family firms found that unfavourable country-level institutional factors, including unstable market conditions and small market size, positively induce internationalization. Precisely, an unfavourable institutional environment is an opportunity for a firm to internationalize (White, Kitimbo, \& Rees, 2019). Based on the discussion, the study, therefore, proposes that:

H1: pull factors that exhibit favourable institutional environment factors have a positive influence on SMEs internationalization.

H2: push factors that exhibit unfavourable institutional environment factors have a positive influence on SMEs internationalization.

\section{Methodology}

This paper applied a survey research strategy (Zaiem \& Zghidi, 2011) to examine the drivers of SMEs internationalization. An online questionnaire (google docs) (Bowen, 2019) was used to collect suitable primary data from indigenous Ghanaian exporting firms between January 2020 to June 2020. The Ghanaian exporters represent a proper context for this research due to their enormous contribution, not excluding their challenges. For instance, their contribution to the employment section accounts for $85 \%$ in the manufacturing sector, $85 \%$ in all the established individuals and private enterprises and $70 \%$ to the Ghanaian Gross Domestic Product (GDP) (International Trade Centre, 2016). Moreover, in the non-traditional export sector, exporters contributed a total export earner of $\$ 2.557$ billion in 2017 (GEPA, 2017). However, despite their contributions, SMEs in Ghana face numerous challenges, such as difficulty in sustaining and expanding business which constrains their international activities (GEPA, 2017; International Trade Centre, 2016; Takyi \& Naidoo, 2020).

Three hundred indigenous exporters were contacted through email and invited to participate in the survey study. The link to the questionnaire was attached to the email, which redirected the respondents to the questionnaire set (Hofer \& Baba, 2018). The questionnaire guide focused on the pull and push drivers of internationalization developed from institutional dimensions (formal and informal). The study also resorted to peer-reviewed journals, reliable documents, and website content as the main sources of secondary information (Saunders, Lewis, \& Thornhill, 2016). The study adopted a purposive sampling technique to select the indigenous exporters (defined as exporter SMEs who own at least 65\% share of the company) from the Ghana Export Promotion Authority export directorate and have been in export for at least three years (Quaye et al., 2017). In all, a total of 109 participants responded to the online questionnaire. The study selected key informants, including owner/manager, Chief Executive Officer (CEO), export manager and sector head who are actively involved in the export activities of the firm and have in-depth knowledge on the question under research (Lages, Jap, \& Griffith, 2008; Saunders, Lewis, $\&$ Thornhill, 2007). The data were analyzed using STATA version 13 software. Also, Pearson correlation, linear regression and multiple regress were used to determine the variables' relationship.

In the measurement of the independent variables, all the drivers of internationalization were measured directly. The study used multi-item to operationalize all variables and presented a list of all pull and push factors to respondents. Participants were then asked to indicate what factors influenced their internationalization decision. A seven-point Likert scale adapted from (Quaye et al., 2017) was used to rate their reasons for entering a foreign market from [1] Not at all in agreement to [7] Extremely in agreement. With the measurement of the dependent variable, scholars argued for using multiple-item measurements of internationalization due to its reliability (Li, 2018). However, others argue that the multiple-item measurement might hide each element's impact on 
internationalization (Ramaswamy, Kroeck, \& Renforth, 1996). Therefore, the study measured the internationalization based on a single item measurement as a percentage of foreign sales to the total firm sales ( $\mathrm{Li}$, 2018).

This study controlled three key variables: firm age, size, and education. Studies have shown that the firm's age has both positive (Welch \& Wiedersheim - Paul, 1980) and negative (Das, 1994) impact on internationalization. Therefore, the study controlled for the firm age and operationalized as the number of years in operations (Idris \& Saridakis, 2018). Firm size is measured as the number of employees (Ciszewska-Mlinaric, 2018) and further grouped into $1=$ micro (employing five or less); $2=$ small (employing 6-29); $3=$ medium-sized (employing 30 to 99) and; 4=large (employing 100 and above) (Aboagye, 2006). Lastly, the paper controlled for respondents' education by asking them to indicate their level of education. Later the study harmonized their responses and coded them as 1=No formal education, 2= Junior High School, 3=Form four/ Senior High School (high school), 4= Diploma and 5= University first degree and above. Literature proxy education as human capital and found that education influences internationalization (Bates, 1990b).

\section{Presentation of Results}

Characteristics of the exporters are presented in Table 1. Three industries participated in the study, with the majority falling under the agriculture industry, while fully owned Ghanaian export firms represent $95 \%$. The distribution of the employees includes 67 small firms and one large firm.

Table 1: Descriptive analysis

\begin{tabular}{|l|l|l|l|}
\hline & Responses & Number & \% \\
\hline \multirow{4}{*}{ Size of firm } & $1-5$ & 28 & 25.69 \\
\cline { 2 - 4 } & $6-29$ & 67 & 61.47 \\
\cline { 2 - 4 } & $30-99$ & 13 & \\
& Over 100 & 1 & 11.93 \\
\hline \multirow{3}{*}{ Ownership structure of the firm } & $65-99 \%$ Ghanaian & 15 & 0.92 \\
\cline { 2 - 4 } & & & 13.76 \\
\hline \multirow{3}{*}{ Nature of business } & $100 \%$ Ghanaian owned & 94 & 86.24 \\
\hline & Manufacturing & 31 & 28.44 \\
\cline { 2 - 4 } & Agriculture & 56 & 51.38 \\
\cline { 2 - 4 } & Handicraft & 22 & 20.18 \\
\hline
\end{tabular}

Source: Field data 2020

Presentation of results for hypothesis 1

Table 2: Results of Pearson correlation

\begin{tabular}{|l|c|}
\hline & Internationalization \\
\hline Pull factors & -0.2537 \\
\hline Age of firm & 0.0285 \\
\hline Size of firm & 0.1602 \\
\hline Education & 0.1719 \\
\hline
\end{tabular}

\section{Source: Field data, 2020}

Hypothesis 1 indicates that pull factors positively drive indigenous SMEs internationalization. Table 2 shows the Pearson correlation analysis results for the level of internationalization, pull drivers, and control variables such as the firm's age, size of the firm, and education. The table shows correlation coefficient $r$, between the dependent variable and the independent variable, and the control variables, ranging between 0.02 and -0.30 approximately. The result shows that pull drivers have a negative linear relationship ( -0.3 approximately) with internationalization, whereas firm size has a positive relationship (0.2) with internationalization (Ciszewska-Mlinaric, 2018; Williams, 2011). However, the relationship between pull drivers, firm size with internationalization is weak. Similarly, education recorded a positive (weak) effect on internationalization, which depicts that the higher the level of one's educational qualification, the higher the international activities. By implication, education serves as a platform to acquire specific knowledge to boost the individual capability and develop a competitive advantage in both the domestic and foreign markets. Thus, the higher the educational level, the higher the firms' human capital (education treated via human capital) and the greater the SMEs internationalization (Bates, 1990). Additionally, firms' age had no relationship with internationalization. To answer the research question, "How do the pull factors drive indigenous firms' internationalization?"

A linear regression analysis was conducted. Tables $3 \mathrm{a}$ and $3 \mathrm{~b}$ have regression results that show the influence 
of pull drivers on the level of internationalization. Table 2 shows that the probability $\mathrm{F}$ shows 0.0078 , which is significant and indicates that the regression model was fit to measure the variation between internationalization and pull institutional drivers. Also, the Adjusted R-squared value is 0.055 , meaning pull institutional drivers explain $5.5 \%$ of the variation in the level of internationalization. From Table $3 \mathrm{~b}$, the coefficient for pull drivers is -0.7875 , and it is statistically significant, with a p-value of 0.008 at a $95 \%$ confidence level. This implies that a percentage increase in pull drivers possibly decreases internationalization by $78.76 \%$. Therefore, considering the effect of pull factors on internationalization, we established that pull drivers negatively affect internationalization, rejecting $\mathrm{H} 1$.

Table 3a: ANOVA tables

\begin{tabular}{|l|l|l|l|}
\hline Source & SS & Df & MS \\
\hline Model & 16.718863 & 1 & 16.718863 \\
\hline Residual & 242.96921 & 107 & 2.27074028 \\
\hline Total & 259.688073 & 108 & 2.4045192 \\
\hline
\end{tabular}

\begin{tabular}{|l|l|}
\hline Number of obs & 109 \\
\hline F( 1, 107) & 7.36 \\
\hline Prob > F & 0.0078 \\
\hline R-squared & 0.0644 \\
\hline Adj R-squared & 0.0556 \\
\hline Root MSE & 1.5069 \\
\hline
\end{tabular}

Source: Field data, 2020

Table 3b: Linear Regression results showing the relationship between internationalization and pull drivers

\begin{tabular}{|l|l|l|l|l|l|}
\hline $\begin{array}{l}\text { Firms } \\
\text { Internationalisation }\end{array}$ & Coef. & Std. Err. & $\mathrm{T}$ & $\mathrm{P}>\mathrm{t}$ & {$[95 \%$ Conf. Interval] } \\
\hline Pull drivers & -0.7875728 & 0.2902492 & -2.71 & 0.008 & $-1.362958-0.21219$ \\
\hline cons & 8.310474 & 1.531144 & 5.43 & 0.000 & $5.275159-11.34579$ \\
\hline
\end{tabular}

Source: Field data, 2020

Table 3c: Multiple regression analysis

\begin{tabular}{|l|l|l|l|l|l|}
\hline $\begin{array}{l}\text { SMEs } \\
\text { Internationalisation }\end{array}$ & Coef. & Std. Err. & $\mathrm{T}$ & $\mathrm{P}>\mathrm{t}$ & [95\% Conf. Interval] \\
\hline Pull drivers & -0.7151607 & 0.2932401 & -2.44 & 0.016 & $-1.296667-0.13365$ \\
\hline Age of firm & 0.0159238 & 0.014446 & 1.1 & 0.273 & $-0.0127232-0.044571$ \\
\hline Size of firm & 0.0137245 & 0.0098774 & 1.39 & 0.168 & $-0.0058627-0.033312$ \\
\hline Education & 0.1712615 & 0.1298884 & 1.32 & 0.19 & $-0.086312-0.428835$ \\
\hline cons & 6.738142 & 1.748092 & 3.85 & 0.000 & $3.271611-10.20467$ \\
\hline
\end{tabular}

\section{Source: Field data, 2020}

A multiple regression model was adopted to examine the effect of the control variables (firm age, size and education) on the relationship between internationalization and pull drivers. The results are shown in Table 3c. Table $3 c$ shows that the coefficient for pull drivers is -0.715 , and it is significant ( $p$-value $<0.05$ ) at a $95 \%$ confidence level. However, the coefficients of the firm's age, size of firm and education, which are $0.0159,0.0137$ and 0.1712 , respectively, were not statistically significant at a $95 \%$ confidence level. Thus, a percentage increase in pull drivers (in the presence of control variables) is likely to decrease internationalization by $71.5 \%$. The multiple regression seems to suggest that age, size and education may improve SMEs internationalization. However, they did not show significance, yet their inclusion brought a change (from $78.78 \%$ to $71.5 \%$ ) in the internationalization value. However, based on Tables $3 \mathrm{~b}$ and Table $3 \mathrm{c}$, the null hypothesis is rejected.

Table 4 shows the results of Pearson correlation analysis for internationalization and push factors as well as the control variables such as the age of the firm, size of firm and education. In this table, the correlation coefficient 
$\mathrm{r}$ between the dependent variable (internationalization) and the independent variable (push drivers) was 0.06 . Similarly, the Pearson correlation $r$, for internationalization and age of the firm, size of the firm, and respondents' education are $0.02,0.16$ and 0.17 , respectively. This implies no linear relationship between internationalization and push drivers and the firm's age. However, there seems to be a very weak linear relationship between internationalization and control variables such as firm size and education with $\mathrm{r}$ values of approximately 0.2 .

Presentation of results for hypothesis 2

\begin{tabular}{|l|c|}
\hline & Internationalization \\
\hline Push drivers & 0.0673 \\
\hline Age of firm & 0.0285 \\
\hline Size of firm & 0.1602 \\
\hline Education & 0.1719 \\
\hline
\end{tabular}

\section{Source: Field data, 2020}

In answering the research question for $\mathrm{H} 2$, a linear regression analysis was conducted, as shown in tables 5a and $5 \mathrm{~b}$. Tables $5 \mathrm{a}$ and $5 \mathrm{~b}$ show a linear regression analysis between internationalization and push factors.

The ANOVA tables show a probability F and the Adjusted R-squared values of 0.359 and -0.001 , respectively. The F-probability is not significant and cannot be said to be fit. From Table 4b, the regression coefficient for push drivers was 0.085 with $p>0.05$, and it is not significant. The coefficient is positive and shows an $8.5 \%$ increase in internationalization per a given increase in push drivers; hence the null hypothesis is rejected. To test the impact of the control variables, i.e., age of the firm, size, and education on the relationship between internationalization and push factors, a multiple regression analysis was done as shown in table $5 \mathrm{c}$. From Table $5 \mathrm{c}$, the coefficient for push drivers, the firm's age, the size of the firm, and the education of respondents are shown as $0.2853,0.0112$, 0.0174 and 0.2255 , respectively. Though the coefficients are positive, they are not statistically significant at a $95 \%$ confidence level, confirming the results in Table $5 \mathrm{~b}$ that push drivers to have no significant effect on internationalization. Thus, Hypothesis 2 is tested using a linear regression model and a multiple regression model, presented in Table $5 \mathrm{~b}$ and Table $5 \mathrm{c}$.

Table 5a: ANOVA tables

\begin{tabular}{|l|l|l|l|}
\hline Source & SS & Df & MS \\
\hline Model & 321291895 & 1 & 0.321292 \\
\hline Residual & 40.5961393 & 107 & 0.379403 \\
\hline Total & 40.9174312 & 108 & 0.378865 \\
\hline
\end{tabular}

\begin{tabular}{|l|l|}
\hline Number of obs & 109 \\
\hline $\mathrm{F}(1,107)$ & 0.85 \\
\hline Prob $>\mathrm{F}$ & 0.3595 \\
\hline R-squared & 0.0079 \\
\hline Adj R-squared & -0.0014 \\
\hline Root MSE & 0.61596 \\
\hline
\end{tabular}

Source: Field data, 2020

Table 5b: Regression results showing the relationship between internationalization and push drivers.

\begin{tabular}{|c|c|c|c|c|c|c|}
\hline INTERNATIONALISATION & Coef. & Std. Err. & $\mathrm{T}$ & $\mathrm{P}>\mathrm{t}$ & $\begin{array}{l}{[95 \%} \\
\text { Conf. }\end{array}$ & Interval] \\
\hline AVER_PUSH_DRIVERS & 0.0852088 & 0.0925945 & 0.92 & 0.36 & $\begin{array}{l}- \\
0.0983489\end{array}$ & 0.2687666 \\
\hline cons & 2.55236 & 0.5197084 & 4.91 & 0 & 1.522099 & 3.582621 \\
\hline
\end{tabular}

Source: Field data, 2020 
Table 5c: Multiple Regression Analysis

\begin{tabular}{|c|c|c|c|c|c|c|}
\hline $\begin{array}{l}\text { Firms } \\
\text { Internationalisation }\end{array}$ & Coef. & $\begin{array}{l}\text { Std. } \\
\text { Err. }\end{array}$ & $\mathrm{t}$ & $\mathrm{P}>\mathrm{t}$ & [95\% Conf. & Interval] \\
\hline Push drivers & 0.2853679 & 0.2414593 & 1.18 & 0.24 & -0.1934549 & 0.7641907 \\
\hline Age of firm & 0.0112264 & 0.0149199 & 0.75 & 0.453 & -0.0183604 & 0.0408132 \\
\hline Size of firm & 0.0174204 & 0.0103277 & 1.69 & 0.095 & -0.0030598 & 0.0379005 \\
\hline $\begin{array}{l}\text { Education of } \\
\text { Respondent }\end{array}$ & 0.2255003 & 0.1313863 & 1.72 & 0.089 & -0.0350436 & 0.4860442 \\
\hline cons & 1.169845 & 1.529843 & 0.76 & 0.446 & -1.863891 & 4.203581 \\
\hline
\end{tabular}

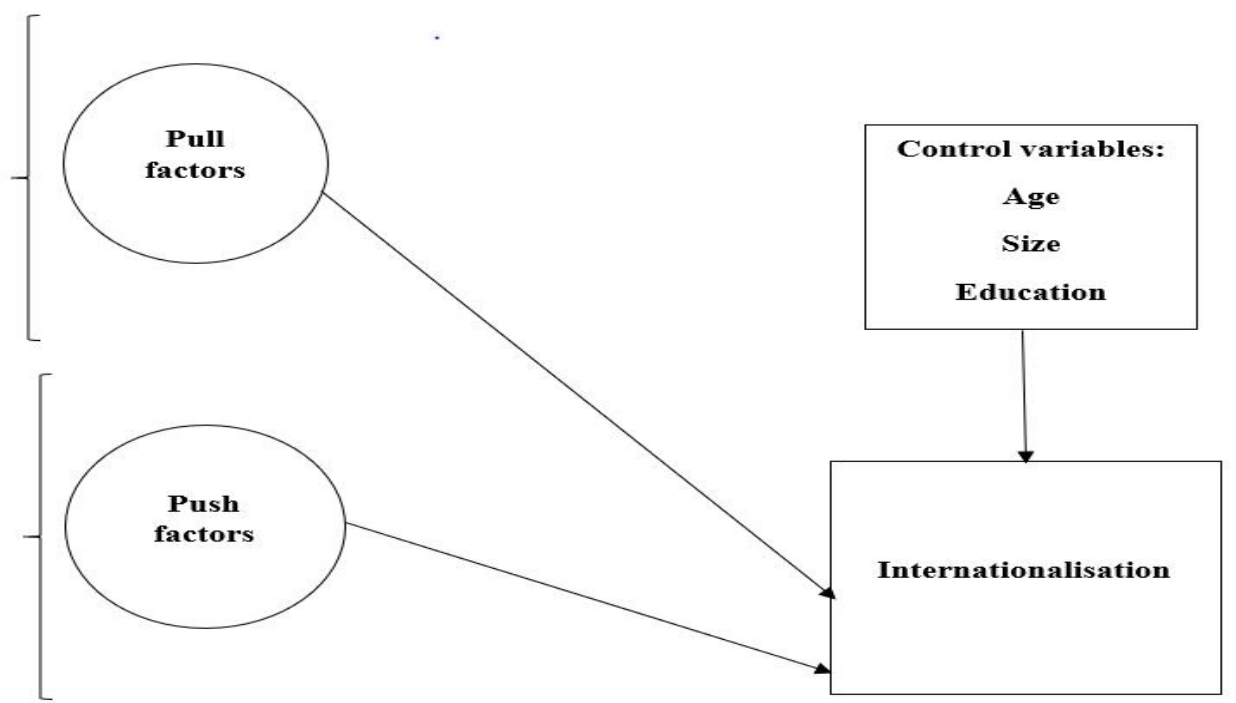

Figure 1: Conceptual model of the study/

\section{Discussion}

The study examined the relationship between institutional environment factors (pull and push factors) and firms' internationalization. The study argues that pull factors (favourable factors) increase the possibility of firms' internationalization (Bowen, 2019). The results of the study suggest that pull factors have a significant impact on firms' internationalization. We found out that positive factors such as low tax rate, access to a credit facility, government incentives, large market size, increase in foreign demands, advanced technology, political stability, and high media publicity significantly influence firms' internationalization, albeit with a negative impact. Besides, the findings of the study suggest that firm size and education qualification have a positive impact on firms' internationalization despite their insignificant effect.

In contrast, the results of the push factors suggest that high tax, lack of government incentives, unfriendly media publicity, small domestic market, high competition have an insignificant positive effect on firms' internationalization.

Scholars suggest that favourable environment factors (as a proxy to pull factors) positively drives firms' internationalization decision (Monticelli et al., 2017; Omokaro - Romanus et al., 2018). Moreover, Bowen (2019) found out that a favourable institutional environment positively impacts internationalization. This study offers contrary findings to the previous study on pull factors (Bowen, 2019; Francioni et al., 2016; Omokaro - Romanus et al., 2018; Seglah \& Armah, 2016). However, it complements the push drivers, considered unfavourable factors (Crick, 2004; Hollensen, 2014; Kraus et al., 2017) and revealed that the pull and the push factors within a different context under the global market crises might exhibit different effects on internationalization. While the pull factor revealed a significant negative relationship, the results of the empirical study reveal a positive and non-significant effect of push factors on internationalization.

The findings add a sense of intricacy to the existing internationalization research and reveal new empirical 
perspectives on the effects of environmental factors on the possibility of driving international activities. The finding suggests that a favourable environment attenuate internationalization, which is contrary to the extant study (Bowen, 2019). Accordingly, the findings seem to imply that a favourable domestic environment can be a "fertile ground for entrepreneurs to take advantage of the opportunities and enter the market with creative offerings and satisfy their internal attributes of need for achievement" without operating outside the national boundaries (Muralidharan \& Pathak, 2017:4). Consequently, firms can take advantage of the opportunities created in the domestic environment because of the favourable environment to develop their competitive advantage, creativity and innovativeness at the local level; because the favourable environmental factors have reduced the uncertainty of operating in the domestic market, which may have driven a firm to operate outside the country's territories (Muralidharan \& Pathak, 2017).

Furthermore, the study found that firms' age, size, and educational qualification are used as drivers of internationalization (Ciszewska-Mlinaric, 2018; Idris \& Saridakis, 2018; Li, 2018) have no significant impact on SMEs internationalization. The study findings complement the previous study that firms' age has no significant effects on internationalization (Williams, 2011) but contradicts that of (Li, 2018). The findings of the study seem to imply that firm age, size and education, which correlates with experience, economy of scale, and human capital (Bates, 1990b; Childs \& Jin, 2015; Samiee \& Walters, 1991), may not play a significant role in SMEs internationalization if the exporting have an alliance with an international agent (Morais \& Franco, 2018). Such an alliance will increase the firm's international experience, which they can leverage to develop a competitive advantage and enhance international operations (Monticelli et al., 2017; Safari \& Saleh Ali, 2020).

Therefore, managers of exporting firms may consider building their business strategy such as a strategic alliance with a local or an international agent; such alliance can enhance the firm international experience, improve market knowledge and boost the chances of exporting to a new market (Morais \& Franco, 2018). Williams (2011) offered a similar conclusion that age might not significantly influence export activities; however, the firm's use of internal networks and social networks may positively enhance their internationalization (Idris \& Saridakis, 2018).

To confirm the impact of the control variables under the pull factors, a multiple regression was conducted to test the relationship between firms' age, size, education, and internationalization. The results of the multiple regression analysis seem to imply that SMEs exporters can improve their international activity $(78.78 \%$ to $71.5 \%$, see Table 3c) with the inclusion of the firm size, age and educational qualification $(1.59 \%, 0.013 \%$ and $0.171 \%$ respectively). The findings indicate that firms' importance, such as age, size, and education, cannot be completely ruled out in the firms' degree of internationalization. The value depicts the possibility that the degree of internationalization may also be dependent on the strength of the firm characteristics. Therefore, owners/managers can undertake courses to develop their education qualifications whiles networking to improve their international knowledge.

The study uses the institutional-based view to explore the link between domestic institutional environment factors and SMEs internationalization. The institutional theory argues that SMEs internationalization is mostly driven by the home country institutional factors (Igwe Paul \& Kanyembo, 2019) and the motivation to internationalize or not depends on the national context (Muralidharan \& Pathak, 2017). Exporters are facilitated by the institutional environment conditions such that the SMEs garner motivation from the existing environmental condition to induce export activities. Thus, usually, the domestic institutional context influences firms' internationalization.

Extant studies on institution and internationalization suggest that firms leverage on favourable domestic institutional environment factors such as large domestic market, tax benefits, low-interest rates, subsidies, foreign market requests, business contacts, among others internationalize (Bowen, 2019; Epifanova et al., 2015; Monticelli et al., 2017; Omokaro - Romanus et al., 2018). Furthermore, White et al. (2019) suggest that unfavourable institutional environmental conditions trigger internationalization. This study examined the relationship between pull and push factors and indigenous firms' internationalization based on the institutional theory. The study results suggest that push factors, firm age, size and educational qualification are insignificant in firms' internationalization.

However, on the pull factors, when the institutional condition was favourable, export activity reducedfavourable domestic factors led to a decrease in the internationalization of firms. These results explained the argument that a favourable national environment "reduces the uncertainty of success" (Muralidharan \& Pathak, 2017:4) of opening businesses in the domestic market hence motivating firms with a high desire to succeed to take advantage of the favourable condition and enter the market with new and creative product and develop their competitive advantages.

While favourable domestic environment factors create a fertile and friendly atmosphere for developing innovative products or services and build domestic competitiveness, the unfavourable factors, however, creates a hostile condition that firm may want to take their business outside the national territories to avoid the 'uncertainty of success' whiles taking advantage of the foreign market opportunities.

Therefore, favourable environmental factors (as a proxy to pull factors) positively induce firms' internationalization decisions (Bowen, 2019; Marinova \& Marinov, 2017; Monticelli et al., 2017; Omokaro - 
Romanus et al., 2018; Tiger, 1999).

However, because the environment is dynamic and deeply embedded in the environment (Edquist, 1997), any prevailing environmental conditions may influence their activities (Muralidharan \& Pathak, 2017). Consequently, it is also likely to attribute the differing findings found for the relationship between pull and firms' internationalization on the current global environmental conditions. A global crisis (i.e., COVID-19 pandemic) may decrease market demands and terminate international orders (Shafi, Liu, \& Ren, 2020). Notwithstanding the study's findings, the results seem to support the argument in the institutional-based view that institutional factors boost or limit international decisions and produce negative, positive, or indifferent results (Monticelli et al., 2017). By implication, in the internationalization perspective, unfavourable conditions in the international market may affect the export distribution channel (such as the alliance with an international agent), reduce export activities and foreign sales in the country leading market destination, including the Netherlands, United Kingdom, France, United States (GEPA, 2017): which can attenuate export to the leading European market, such as United Kingdom, France, Italy, Spain, Germany (GEPA, 2017) thereby affect export activities and reduce foreign sales. Thus, despite favourable environmental factors in the home country, a condition in the global and international market may reduce export activities, affecting internationalization.

\section{Conclusion, Limitations, and Recommendations}

This study explored the domestic institutional factors (favourable and unfavourable) that drive internationalization by using data set of 109 Ghanaian exporters. The study further used a structured questionnaire to gather data from key informants of exporters in non-traditional crops in Ghana. This research highlights the significant role of pull institutional factors that drives indigenous firms' internationalization in the market where there is the need for more institutional research studies. The result uncovered that some pull institutional factors such as low tax rate, high media representation, political stability, increased international demands, government incentives, access to credit facilities play a critical role in local firms' international operations.

The implications of this study highlight the importance of policymakers, specifically, the need for the government to assists indigenous exporters through, specific training and workshop programs about how to develop new export strategies (Safari \& Saleh Ali, 2020), improve exporters competency and adapt to new strategies in the situation of an environmental change, especially global pandemic. Secondly, government training programs need to help exporters understand the global business market changes and develop a new export strategy. Moreover, the government can appoint an export intermediary to facilitate export activities since individual export, especially for the micro and smaller firms, may be difficult due to the global pandemic. Lastly, the government can empower local firms to take advantage of the global crisis's benefits. However, despite the highlighted contributions, the study has other limitations.

One, internationalization was measured with a single-item scale; percentage of foreign sales to total sales thereby limiting comprehensive insights into other internationalization scale measurements $(\mathrm{Li}, 2018)$ and how country-level pull and push factors influence internationalization. Precisely, the study recommends future research to examine internationalization in terms of geographical diversification, top management international experience, foreign production, research, and development (Ciszewska-Mlinaric, 2018; Ramaswamy, 1992; Sullivan, 1994).

Lastly, the study fails to consider the potential effect of a mediator on exporting firms' internationalization. The study argues that the inclusion may give a different insight into how pull and push factors influence firms' internationalization. The dynamic nature of the global environment may change significantly and influence export activities; hence, an in-depth study on the impact of a global crisis (such as COVID-19) on indigenous exporters can be considered for future research. Also, the future study can investigate the specific institutional factors influencing firms' degree of internationalization. The contrary findings on the effect of pull (favourable) and push factors (unfavourable) on internationalization must be considered conservatively because of the above limitations.

\section{Acknowledgement(S)}

The study expresses gratitude to the GEPA for releasing their export directorate to us. Also, we are thankful to the individual exporters who responded to our questionnaire.

\section{References}

Aboagye, A. Q. Q. (2006). Cointegration and causality analysis of Ghanaian exports, foreign, domestic and human capital. African Journal of Business and Economic Research, 1(2_3), 130-152. Retrieved from https://journals.co.za/content/aa_ajber/1/2_3/EJC10405

Amungo, E. (2016). Examining the factors influencing the international expansion of Nigerian banks. In Africato-Africa Internationalization (pp. 69-98): Springer.

Bates, T. (1990). Entrepreneur human capital inputs and small business longevity. The Review of Economics and Statistics, Vol. 72(No. 4), 551-559.

Boso, N., Adeleye, I., Ibeh, K., \& Chizema, A. (2019). The internationalization of African firms: Opportunities, 
challenges, and risks. Thunderbird international business review, 61(1), 5-12.

Bowen, R. (2019). Motives to SME internationalization: A comparative study of export propensity among food and drink SMEs in Wales and Brittany. Cross Cultural \&amp; Strategic Management, 27(1), 67-90. doi:10.1108/CCSM-08-2018-0125

Childs, M. L., \& Jin, B. (2015). Firm factors that influence internationalization and subsequent financial performance of fashion retailers. Journal of Service Theory and Practice, 25(1), 95-114. doi:10.1108/JSTP09-2013-0204

Ciszewska-Mlinaric, M. (2018). Export Intensity, Geographic Diversification and the Role of Public Support: The Evidence from Old and New Europe SMEs. Entrepreneurial Business and Economics Review, 6(2), 45-69.

Crick, D. (2004). U.K. SMEs' decision to discontinue exporting: an exploratory investigation into practices within the clothing industry. Journal of Business Venturing, 19(4), 561-587. doi:https://doi.org/10.1016/S08839026(03)00032-6

Das, M. (1994). Successful and Unsuccessful Exporters from Developing Countries: Some Preliminary Findings. European journal of marketing, 28(12), 19-33. doi:10.1108/03090569410074237

Edquist, C. (1997). Systems of innovation: technologies, institutions, and organizations: Psychology Press.

Epifanova, T., Romanenko, N., Mosienko, T., Skvortsova, T., \& Kupchinskiy, A. (2015). Modernization of

institutional environment of entrepreneurship in Russia for development of innovation initiative in small business structures. European Research Studies, 18(3), 137.

Francioni, B., Pagano, A., \& Castellani, D. (2016). Drivers of SMEs' exporting activity: a review and a research agenda. Multinational Business Review, 24(3), 194-215.

Fuentelsaz, L., González, C., Maícas, J. P., \& Montero, J. (2015). How different formal institutions affect opportunity and necessity entrepreneurship. Business Research Quarterly, 18(4), 246-258.

GEPA. (2017). Report on Analysis of 2017 Non-Traditional Export statistics. In: Ghana Export Promotion

Authority: Ghana, Accra.

Hofer, K. M., \& Baba, A. (2018). Market Entry Strategies, Innovation and Performance of SMEs in the Service Sector. Key Success Factors of SME Internationalisation: A ross Country Perspective, doi:https://doi.org/10.1108/S1876-66X20180000034009

Hollensen, S. (2014). Global Marketing (6th Ed.). Pearson: Harlow.

Idris, B., \& Saridakis, G. (2018). Local formal interpersonal networks and SMEs internationalization: Empirical evidence from the UK. International Business Review, 27(3), 610-624. doi:https://doi.org/10.1016/j.ibusrev.2017.10.010

Igwe P. A., \& Kanyembo, F. (2019). The Cage Around Internationalisation of SMEs and The Role of Government. In H. Mohamed Yacine, J. Paul, \& O. Adah-Kole Emmanuel (Eds.), International Entrepreneurship in Emerging Markets: Nature, Drivers, Barriers and Determinants (Vol. 10, pp. 161-176): Emerald Publishing Limited.

International Trade Centre. (2016). SME Competitiveness in Ghana: Alliance for Action. In (pp. 47). Geneva: International Trade Centre.

Korsakien, R., Diskien, D., \& Smaliukien, R. (2015). Institutional theory perspective and internationalization of firms. How institutional context influences internationalization of SMEs? Entrepreneurship and sustainability issues, 2(3). doi:10.9770/jesi.2014.2.3(3)

Kraus, S., Mitter, C., Eggers, F., \& Stieg, P. (2017). Drivers of internationalization success: a conjoint choice experiment on German SME managers. Review of Managerial Science, 11(3), 691-716.

Lages, L. F., Jap, S. D., \& Griffith, D. A. (2008). The role of past performance in export ventures: a short-term reactive approach. Journal of International Business Studies, 39(2), 304-325. doi:10.1057/palgrave.jibs. 8400339

Li, T. (2018). Internationalization and its determinants: A hierarchical approach. International Business

Review, 27(4), 867-876. doi:https://doi.org/10.1016/j.ibusrev.2018.01.009

Marinova, S., \& Marinov, M. (2017). Inducing the internationalization of family manufacturing firms from a transition context. European Business Review, 29(2), 181-204. doi:10.1108/EBR-07-2016-0085

Monticelli, J. M., Calixto, C. V., Vasconcellos, S. L. d., \& Garrido, I. L. (2017). The influence of formal institutions on the internationalization of companies in an emerging country. Revista brasileira de gestão de negócios, 19(65), 358-374.

Morais, F., \& Ferreira, J. J. (2020). SME internationalization process: Key issues and contributions, existing gaps and the future research agenda. European Management Journal, 38(1), 62-77. doi:https://doi.org/10.1016/j.emj.2019.08.001

Morais, F., \& Franco, M. (2018). The role of cooperative alliances in internationalization strategy: Qualitative study of Portuguese SMEs in the textile sector. Journal of Strategy and Management, 11(4), 461-482. doi:10.1108/JSMA-03-2018-0023

Muralidharan, E., \& Pathak, S. (2017). Informal institutions and international entrepreneurship. 
International Business Review, 26(2), 288-302.

North, D. C. (1990). Institutions, institutional change, and economic performance Cambridge Univ Press.

Omokaro-Romanus, C., Anchor, J. R., \& Konara, P. (2018) . The internationalization of Nigerian firms:

Motivations and location patterns. Thunderbird international business review, 61(1), 75-88.

Quaye, D. M., Sekyere, K. N., \& Acheampong, G. (2017). Export promotion programmes and export

performance: a study of selected SMEs in the manufacturing sector of Ghana. Review of International Business and Strategy, 27(4), 466-483.

Ramaswamy, K. (1992). Multinationality and performance: A synthesis and redirection. Advances in international comparative management, 7(4), 241-267.

Ramaswamy, K., Kroeck, K. G., \& Renforth, W. (1996). Measuring the Degree of Internationalization of a firm: A Comment. Journal of International Business Studies, 27(1), 167-177. doi:10.1057/palgrave.jibs.8490131

Rialp, A., Rialp, J., \& Knight, G. A. (2005). The phenomenon of early internationalizing firms: what do we know after a decade (1993-2003) of scientific inquiry? International Business Review, 14(2), 147-166. doi:https://doi.org/10.1016/j.ibusrev.2004.04.006

Safari, A., \& Saleh Ali, S. (2020). Key determinants of SMEs' export performance: a resource-based view and contingency theory approach using potential mediators. Journal of Business \& Industrial Marketing, 35(4), 635-654. doi:10.1108/JBIM-11-2018-0324

Samiee, S., \& Walters, P. G. P. (1991). Segmenting corporate exporting activities: Sporadic versus regular exporters. Journal of the Academy of Marketing Science, 19(2), 93-104. doi:10.1007/BF02726001

Saunders, M., Lewis, P., \& Thornhill, A. (2007). Research methods for business students. Harlow: Pearson Education Ltd.

Saunders, M., Lewis, P., \& Thornhill, A. (2016). Research methods for business students (7th ed.). Harlow:

Pearson Education Ltd.

Segal, G., Borgia, D., \& Schoenfeld, J. (2005). The motivation to become an entrepreneur. International Journal of Entrepreneurial Behavior \& Research, 11 (1), 42-57. doi:10.1108/13552550510580834

Seglah, S. K., \& Armah, S. E. (2016). Going regional: internationalization strategies of Ghanaian service companies within the ECOWAS market.

Shafi, M., Liu, J., \& Ren, W. (2020). Impact of COVID-19 pandemic on micro, small, and medium-sized Enterprises operating in Pakistan. Research in Globalisation, 100018. doi:https://doi.org/10.1016/j.resglo.2020.100018

Shane, S. A. (2004). A general theory of entrepreneurship: The individual-opportunity nexus: Edward Elgar Publishing.

Sullivan, D. (1994). Measuring the Degree of Internationalization of a Firm. Journal of International Business Studies, 25(2), 325-342. doi:10.1057/palgrave.jibs.8490203

Takyi, L., \& Naidoo, V. (2020). Innovation and Business Sustainability Among SMEs in Africa: The Role of the Institutions. In G. Yang, T. Sang-Bing, D. Xiaomin, \& X. Chunlin (Eds.), Sustainability in the Entrepreneurial Ecosystem: Operating Mechanisms and Enterprise Growth (pp. 50-74). Hershey, PA, USA: IGI Global.

Tiger, L. (1999). The impact of the marketing-R\&D interface on new product export performance: A contingency analysis. Journal of International Marketing, 7(1), 10-33.

Welch, L. S., \& Wiedersheim-Paul, F. (1980). Initial exports-a marketing failure? Journal of Management Studies, 17(3), 333-344. doi:https://doi.org/10.1111/j.14676486.1980.tb00407.x

White, L., Kitimbo, A., \& Rees, L. (2019). Institutions and the location strategies of South African firms in Africa. Thunderbird international business review, 61(1), 61-73.

Williams, D. A. (2011). Impact of firm size and age on the export behaviour of small locally owned firms: Fresh insights. Journal of International Entrepreneurship, 9(2), 152. doi:10.1007/s10843-011-0073-2

Zaiem, I., \& Zghidi, A. B. Y. (2011). Product adaptation strategy and export performance: The impacts of the internal firm characteristics and business segment. Contemporary Management Research, 7(4). 